\title{
Feeding adaptations of the pearl oysters Pinctada margaritifera and $P$. maxima to variations in natural particulates
}

\author{
H. Yukihira ${ }^{1}$, D. W. Klumpp ${ }^{2, *}$, J. S. Lucas ${ }^{3}$ \\ ${ }^{1}$ Department of Zoology and Tropical Ecology, School of Biological Sciences, James Cook University, Townsville, \\ Queensland 4811, Australia \\ ${ }^{2}$ Australian Institute of Marine Science, PMB 3, Townsville MC, Queensland 4810, Australia \\ ${ }^{3}$ Department of Aquaculture, School of Biological Sciences, James Cook University, Townsville, \\ Queensland 4811, Australia
}

\begin{abstract}
The tropical pearl oysters Pinctada margaritifera (Linnaeus) and P. maxima Jameson are suspension feeders of major economic importance. P. margaritifera occurs in coral reef waters characterised by oligotrophy and low turbidity. $P$. maxima habitats are generally characterised by high terrigenous sediment and nutrient inputs, and productivity levels. These differences in habitat suggest that $P$. margaritifera will feed more successfully at low food concentrations, while $P$. maxima will cope with a wider range of food concentrations and more silty conditions. The effect of varying concentrations of natural suspended particulate matter (SPM) on clearance rate (CR), pseudofaeces production, absorption efficiency (abs.eff.), respired energy (RE) and excreted energy (EE) was determined for $P$. margarititera and $P$. maxima. The resultant scope for growth (SFG) was determined and related to habitat differences between the oysters. There was no selective feeding on organic particles in either species. P. margaritifera had higher CR at low SPM concentration $\left(<2 \mathrm{mg} \mathrm{l}^{-1}\right)$, while $P$. maxima had higher CR under turbid conditions (SPM: $13-45 \mathrm{mg} \mathrm{l}^{-1}$ ). The latter species produced less pseudofaeces in relation to its filtration rates; consequently, this species ingested more SPM than P. margaritifera. $P$. maxima had positive SFG over a wider range of SPM concentrations (up to $30-40 \mathrm{mg}^{-1}$ ) while $P$. margaritifera maximised SFG under low SPM conditions $\left\{<3 \mathrm{mg} \mathrm{l}^{-1}\right\}$. Thus feeding responses and energy balance reflected the typical habitats of each species. $P$. margaritifera retained smaller particles than $P$. maxima, enabling it to consume a wider particle size range of SPM at low food levels. $P$. maxima was adapted to its environments of greater SPM load through greater ingestion rates and higher digestive

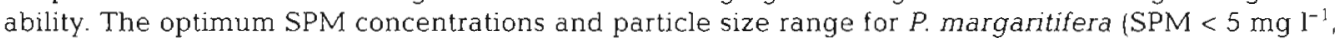
size $>3 \mu \mathrm{m}$ ) and $P$. maxima ( $\mathrm{SPM}=\mathrm{ca} 3$ to $15 \mathrm{mg} \mathrm{l}^{-1}$, size $>4 \mu \mathrm{m}$ ) may be used for selection of optimum pearl culture sites.
\end{abstract}

KEY WORDS: Suspended particulate matter - Turbidity - Pinctada margaritifera Pinctada maxima Suspension-feeding $\cdot$ Scope for growth

\section{INTRODUCTION}

The quantity and quality of suspended particulate matter (SPM) in inshore waters fluctuate depending on oceanographic and meteorological factors such as tidal currents, wind-driven waves, storms and floods. Turbid water contains substantial fractions of inorganic particles, and this has been considered a disadvantage, in bioenergetic terms, for suspension feeding ani-

\footnotetext{
- Addressee for correspondence.

E-mail: d.klumpp@aims.gov.au
}

mals dwelling in such waters. However, some adaptive strategies by temperate and subtropical suspension feeding bivalves, such as preferential ingestion of organic-rich particles and an effective digestive mechanism, act to maximise energy gain under turbid conditions (e.g. Hawkins et al. 1996, Ward \& MacDonald 1996, Barillé et al. 1997, Navarro \& Widdows 1997).

The black-lip pearl oyster Pinctada margaritifera (Linnaeus) and the silver-lip pearl oyster $P$. maxima Jameson (Pteriidae: Bivalvia) are typical filter-feeders in tropical waters. They are relatively fast growing bivalves ( $K$ values 0.2 to 0.5; Gervis \& Sims 1992), and 
are commercially important as the basis of the IndoPacific cultured pearl industries, producing black and silver pearls, respectively. As a key to economic development, the pearl industry has had a rapid expansion in Asia and Oceania over the last decades. Consequently, substantial areas of bays and coral reef atoll lagoons in these regions have been used for pearl culture. Recently, this situation has required more comprehensive environmental management to achieve sustainable development because pearl culture sites and local ecosystems tend to be fully exploited and deteriorate due to the intensive pearl culture. Knowledge of optimal habitat conditions for the pearl oysters is essential for an adequate management scheme.

The natural habitats of Pinctada margaritifera and $P$. maxima are quite different (Gervis \& Sims 1992). $P$. margaritifera is typically found in coral reef waters characterised by oligotrophy and low turbidity. It lives attached by byssal threads to hard substrata on the coral reef. It is most abundant in the atoll lagoons of eastern Polynesia (e.g. 5 million in Penrhyn lagoon and 2 million in Manihiki lagoon, Cook Islands; Sims 1992). On the other hand, Kailola et al. (1993) found that $P$. maxima inhabits a variety of substrata, from mud, sand, gravel, seagrass beds to deepwater 'reefs', living beside sponges, soft corals and whip corals. The habitats in which this latter species is most abundant are generally characterised by substantial amounts of terrigenous sediments combined with high nutrient inputs and productivity levels (Gervis \& Sims 1992, Sims 1993). Adult $P$. maxima release their hold on substrata by losing their byssal threads, and become freeliving on the sea bed.

The ecological differences between Pinctada margaritifera and $P$. maxima suggest that these 2 species would differ in their feeding strategies. For example, $P$. maxima should possess superior ability for coping with high particulate loads, including substantial amounts of inorganic particles. This ability may derive from selective ingestion of organic particles, greater rates of filtration and ingestion, and more efficient digestion in turbid environments. In contrast, $P$. margaritifera should maximise energy gain under environments of low concentrations of SPM.

In laboratory studies, Yukihira et al. (1998b) revealed that Pinctada maxima had higher clearance rates (CR) than $P$. margaritifera at relatively high concentrations of pure microalgae, Dunaliella primolecta and Isochrysis aff. galbana (T-Iso). P. maxima also had higher absorption efficiencies throughout most of the range of food concentrations (range: 0.1 to $11 \mathrm{mg} \mathrm{l}^{-1}$ ). The resultant energy balance of $P$. maxima was maintained positive over wider ranges of food concentration than that of $P$. margaritifera. These results indicated that $P$. maxima was better adapted to waters with greater particulate loads than P. margaritifera. However, Yukihira et al. (1998b) also showed that different food species (D. primolecta and T-Iso) variously affected the ingestion, absorption and respiration of these 2 species of pearl oysters.

Growth or feeding rates of some temperate bivalve species under natural conditions are often considerably different from the results obtained from laboratory experiments. Thus, application of laboratory results to field situations has been questioned (review by Jørgensen 1996). The black mussel Choromytilus meridionalis produced no pseudofaeces when feeding on natural food over the range ca 3 to $17 \mathrm{mg} \mathrm{l}^{-1}$, for which average food absorption efficiency (abs,eff.) was $40 \%$. In contrast, mussels fed on a pure algal diet of Dunaliella primolecta had zero abs.eff. at ca $4 \mathrm{mg} \mathrm{l}^{-1}$, and produced pseudofaeces from ca $6 \mathrm{mg} \mathrm{l}^{-1}$ (Griffiths 1980a). Griffiths (1980a,b) concluded that experiments using $D$. primolecta were not directly applicable to the field. Riisgard (1991) suggested that the comparatively low growth rates of Mytilus edulis in laboratory studies using pure algal diets may be due to the use of unnaturally high algal concentrations that lead to suboptimal conditions (valve closure, reduced metabolism and reduced growth). Navarro et al. (1996) found that the occurrence of inorganic particles in the ingesta of mussels $M$. galloprovincialis enhanced absorption of microalgae in the field.

These results suggest that pearl oysters feeding on natural SPM may also show different patterns of feeding and energy budgets to those found in laboratory studies. Therefore, it was important to extend our laboratory experiments on feeding and energetics to conditions with natural SPM, considering the crucial aspect of comparative effects of inorganic particles on feeding in the 2 species.

The aims of this study were, therefore: (1) to quantify and compare feeding (filtration, pseudofaeces production, selective feeding on organic particles, and absorption), respiration, ammonia excretion and resultant energy budgets (= scope for growth) of Pinctada margaritifera and $P$. maxima feeding on natural food particles, including effects of natural fluctuations in food quantity and quality; (2) to relate these results to habitat differences between the 2 species of pearl oyster.

\section{MATERIALS AND METHODS}

Pearl oysters. Pinctada margaritifera (126 to $146 \mathrm{~mm}$ shell height, 5.5 to $8.8 \mathrm{~g}$ dry soft tissue, $\mathrm{n}=15$ ) were obtained from a floating long-line at Orpheus Island Research Station and P. maxima (111 to $150 \mathrm{~mm}$ shell height, 2.3 to $5.5 \mathrm{~g}$ dry soft tissue, $\mathrm{n}=15$ ) were obtained from a pearl culture company located at 


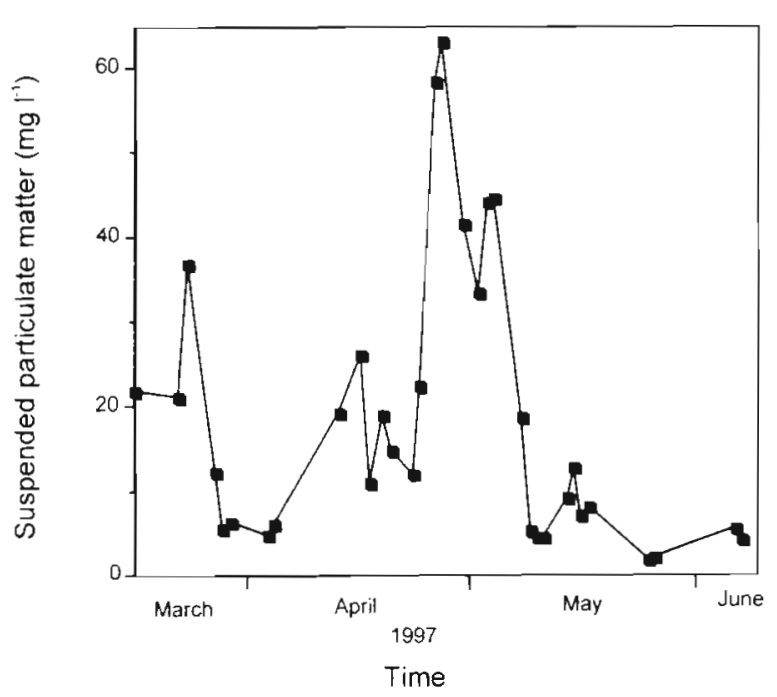

Fig. 1. Variation in amount of suspended particulate matter (SPM) in the water column at the Australian Institute of marine Science (A.IMS) pontoon site from March to June 1997

nearby Hinchinbrook Channel, North Queensland. Oysters were kept suspended in pocket nets (see Gervis \& Sims 1992, Fig. 6F) at $1.5 \mathrm{~m}$ depth beneath a pontoon located in Bowling Green Bay, North Queensland, near the Australian Institute of Marine Science (AIMS). They were acclimated there for at least $2 \mathrm{wk}$ before use in experiments.

Experimental design. Experiments were mainly conducted at the above pontoon. Ambient water was continuously pumped from the acclimation site into a $200 \mathrm{l}$ experimental tank at a rate of $\mathrm{ca} 900 \mathrm{l} \mathrm{h}^{-1}$. The lowest concentration of suspended particulate matter (SPM, $\mathrm{mg}^{-1}$ ) recorded at the pontoon site during the study was $1.95 \mathrm{mg} \mathrm{l}^{-1}$ (Fig. 1). Therefore, lower SPM concentrations ( 0.80 to $3.57 \mathrm{mg} \mathrm{l}^{-1}$ ) were obtained by conducting additional experiments in the AIMS aquarium system, which uses pre-settled Bowling Green Bay water. Water temperature ranged between 23 and $28^{\circ} \mathrm{C}$ during the pontoon and aquarium experiments.

Three individuals of each oyster species were thoroughly cleaned of epibiota and transferred to the 2001 experimental tank $2 \mathrm{~d}$ before experiments began. Oysters were used 3 or 4 times over a week for a series of physiological measurements, and then replaced with a fresh set of oysters from the pontoon site. Faeces and pseudofaeces that had been ejected by oysters were carefully removed from the tank using a siphon, then a plastic tray ( $25 \mathrm{~cm}$ width $\times 30 \mathrm{~cm}$ length $\times 9 \mathrm{~cm}$ height) was slipped beneath each oyster. A piece of plastic attached to the inside of each tray effectively separated the deposited faeces and pseudofaeces The faeces appeared as dark grey ribbons or fragile pellets and were deposited close to the exhalent opening. The pseudofaeces were ejected from the anterior to ventral margin and were mucus-like, light grey, and fragile masses. Water samples were collected from the region surrounding the inhalent opening of the oysters and from the outlet of the experimental tank for measurement of SPM volume using a Coulter Multisizer. The water in the tank was thoroughly mixed by the inflowing seawater; hence differences in SPM volume between inhalent openings of oysters and the tank outlet were small (less than 10\%). Experiments lasted for 2 to $3 \mathrm{~h}$ depending on the production rate of faeces and pseudofaeces. At the end of the experiment, faeces and pseudofaeces of each oyster were separately collected. The above techniques are based on Hawkins et al. (1996).

Availability of natural suspended particulate matter. Gut transit times were monitored in 6 individuals of each species that had been fed on natural SPM and kept undisturbed for at least $2 \mathrm{~h}$ in the experimental tank. They were fed a 20 min pulse of dry alga Tetraselmis suecica as a marker and then supplied with more natural running seawater (= time A). Gut transit time was defined as the time between time A and reappearance of natural dark grey faeces after all the yellow-green algal faeces of $T$. suecica had been defaecated. Gut transit times for Pinctada margaritifera and $P$. maxima were $42 \pm 10$ (SE) and $56 \pm 11$ (SE) min, respectively. Assuming that pseudofaeces are produced immediately after filtration (i.e. 0 min after filtration), 2 water samples of 21 were collected from the outlet of the tank about $25 \min (=\{[42+0] \div 2+[56+0] \div 2\} \div 2)$ before each experiment commenced, and another 2 samples of $2 \mathrm{l}$ about $25 \mathrm{~min}$ before the completion of experiments. The water samples $(n=4)$ were filtered onto separate pre-rinsed, ashed and weighed Whatman GF/C filters. All filters were dried at $60^{\circ} \mathrm{C}$ and weighed, then ashed at $450^{\circ} \mathrm{C}$ for $5 \mathrm{~h}$ and re-weighed to provide organic content (OC, fraction) and particulate organic matter (POM, $\mathrm{mg} \mathrm{l}^{-1}$ ) of each sample.

Three individuals of each species were placed in the $200 \mathrm{l}$ experimental tank with water of low SPM concentration $\left(1.9 \mathrm{mg} \mathrm{l}^{-1}\right)$ and left undisturbed for at least $2 \mathrm{~h}$. Water samples were then collected from the vicinity of the inhalent opening and from inside the exhalent opening using a siphon at a low suction rate ( $<90 \mathrm{ml} \mathrm{min}^{-1}$ ). Concentrations of particles (by volume) from each of 13 particle size classes spanning the range between 1.4 and $10.0 \mu \mathrm{m}$ mean diameter were determined using a Coulter Multisizer. The volume of each sample counted was $12 \mathrm{ml}$. The fraction of each size class retained by the oysters was calculated as retention efficiency, $1-C_{\mathrm{e}} / C_{1}$, where $C_{\mathrm{e}}$ and $C_{1}$ are the concentration of particles in the exhalent and inhalent water, respectively. Production of faecal and other particles via the exhalent siphon was controlled by coinci- 
dent measurements of the particles generated by oysters kept in $0.45 \mu \mathrm{m}$ filtered seawater, following Klumpp et al. (1992).

To determine the SPM particle size composition (by volume), a 21 water sample was collected from the acclimation site under different conditions of low $2 \mathrm{mg}$ $\mathrm{l}^{-1}$ ) and high (29 and $44 \mathrm{mg} \mathrm{l}^{-1}$ ) SPM concentration. Analyses of size composition by volume of SPM ranging from 1.4 to $44.4 \mu \mathrm{m}$ mean diameter were undertaken using the Coulter Multisizer.

Feeding. Samples of faeces and pseudofaeces were analysed for dry weight and organic fraction in the same manner as described above to quantify SPM concentration, OC and POM. Clearance rates (CR, l h h $)$ were calculated using the expression: $\mathrm{CR}=$ ( $\mathrm{mg}$ inorganic matter egested both as faeces and pseudofaeces $\left.\mathrm{h}^{-1}\right) \div\left(\mathrm{mg}\right.$ inorganic matter available $\mathrm{l}^{-1}$ seawater), (Hawkins et al. 1996).

Oysters were sacrificed at the end of experiments. Their soft tissues were dried at $60^{\circ} \mathrm{C}$ and then weighed. $C R$ and rejection rate $(R R=m g$ total pseudofaeces ejected $\mathrm{h}^{-1}, \mathrm{mg} \mathrm{h}^{-1}$ ) were size-standardised to those for an equivalent individual of $10 \mathrm{~g}$ dry soft tissue wt as follows:

$$
Y s=\left(W_{s} / W e\right)^{b} Y e
$$

(Navarro et al. 1991)

where $Y s$ is the size-standardised physiological rate, Ws is the standard size (10 $\mathrm{g}$ dry tissue weight), We is the dry tissue weight of experimental oyster, $b$ is the size exponent: 0.61 (Yukihira et al. 1998a), and $Y e$ is the uncorrected physiological rate.

Respiration and ammonia excretion. Respiration rates $\left(\mathrm{R}, \mathrm{ml} \mathrm{O} \mathrm{O}_{2} \mathrm{~h}^{-1}\right)$ were determined in sealed chambers (2.3 l), 3 containing an experimental oyster and 2 serving as a control without an oyster. Oxygen was measured with YSI dissolved oxygen electrodes (Model 55). Three individuals from each pearl oyster species were kept in the tank used for the feeding experiments for at least $2 \mathrm{~h}$ before measuring respiration. After this, each oyster was placed into a sealed chamber filled with seawater from the flow-through tank. Water in each chamber was thoroughly mixed by a magnetic stirrer, which was separated from the oyster by a mesh partition. Oxygen concentration in each chamber was monitored at 5 min intervals for 10 or 15 min after initial equilibration in the chamber Measurements of $\mathrm{R}$ were conducted over conditions of 10 different SPM concentrations (1 to $63 \mathrm{mg} \mathrm{l}^{-1}$ ). $\mathrm{R}$ was determined after Bayne et al. (1985) and size-standardised to $10 \mathrm{~g}$ soft tissue dry wt using the size exponents, 0.439 for Pinctada margaritifera and 0.543 for $P$. maxima (Yukihira et al. 1998a). Respired energy (RE, J h ${ }^{-1}$ ) was calculated assuming $1 \mathrm{ml} \mathrm{O}_{2}=20.33 \mathrm{~J}$.

The rate of ammonia excretion ( $\mathrm{E}, \mu \mathrm{g} \mathrm{NH}_{4}-\mathrm{N} \mathrm{h}^{-1}$ ) was determined for all oysters as follows. On comple- tion of each feeding experiment, 2 oysters of each species were placed individually in chambers containing $1 \mathrm{l}$ of $0.45 \mu \mathrm{m}$ filtered seawater. The 4 chambers with oysters and the 2 control chambers containing only filtered seawater were left undisturbed for $60 \mathrm{~min}$. Duplicate $10 \mathrm{ml}$ water samples were collected from each chamber, passed through a $0.45 \mu \mathrm{m}$ filter and analysed for ammonia using the phenolhypochlorite method (Solorzano 1969). E was determined following Bayne et al. (1985) and size-standardised to $10 \mathrm{~g}$ soft tissue dry wt using the size exponents, 0.642 for Pinctada margaritifera and 0.789 for $P$. maxima (Yukihira et al. 1998a). Excreted energy (EE, $\mathrm{J} \mathrm{h}^{-1}$ ) was calculated assuming $1 \mathrm{mg} \mathrm{NH}_{4}-\mathrm{N}=$ $24.87 \mathrm{~J}$

Scope for growth. The energy content of absorbed organic matter was $11.8 \mathrm{~J} \mathrm{mg}^{-1}$, as determined from water samples collected in summer and winter (Yukihira 1998). Hence, absorbed energy (AE) of standard $10 \mathrm{~g}$ oysters was calculated as $\mathrm{AE}\left(\mathrm{J} \mathrm{h}^{-1}\right)=11.8\left(\mathrm{~J} \mathrm{mg}^{-1}\right)$ $x$ organic matter absorbed $\left(\mathrm{mg} \mathrm{h}^{-1}\right)$. Scope for growth (SFG, $\mathrm{J} \mathrm{h}^{-1}$ ), the energy oysters have available for growth and reproduction, was calculated as in Bayne et al. (1985) and Warren \& Davis (1967):

$$
\mathrm{SFG}=\mathrm{AE}-\mathrm{RE}-\mathrm{EE}
$$

Statistical analysis. Selective feeding on organic particles was examined by comparing mean organic fraction in pseudofaeces with OC of SPM. using a 2way ANOVA. The relationships between SPM concentration and each of the parameters, CR, pseudofaeces production, abs.eff., AE, RE and EE were determined using regression analyses. When the regressions for both oyster species were linear, the similarity in slopes and intercepts were tested by ANCOVA. When the relationships were otherwise (e.g. logarithmic vs exponential regressions), then the mean values for each comparable SPM concentration were compared between species using a 2-way ANOVA. Data were tested for normality before being subjected to parametric statistics

\section{RESULTS}

\section{Suspended particulate matter}

SPM at the experimental site (AIMS) fluctuated greatly from 1.95 to $63.2 \mathrm{mg} \mathrm{l}^{-1}$ (Fig. 1). The organic fraction (OC) of SPM as a measure of food quality varied between 0.63 and 0.13 . The relation between SPM concentration and organic fraction at the experimental site (Fig. 2a) was expressed by the equation:

$O C=0.354 \times S^{-0.253} \quad\left(r^{2}=0.53, n=31, p<0.001\right)$ 

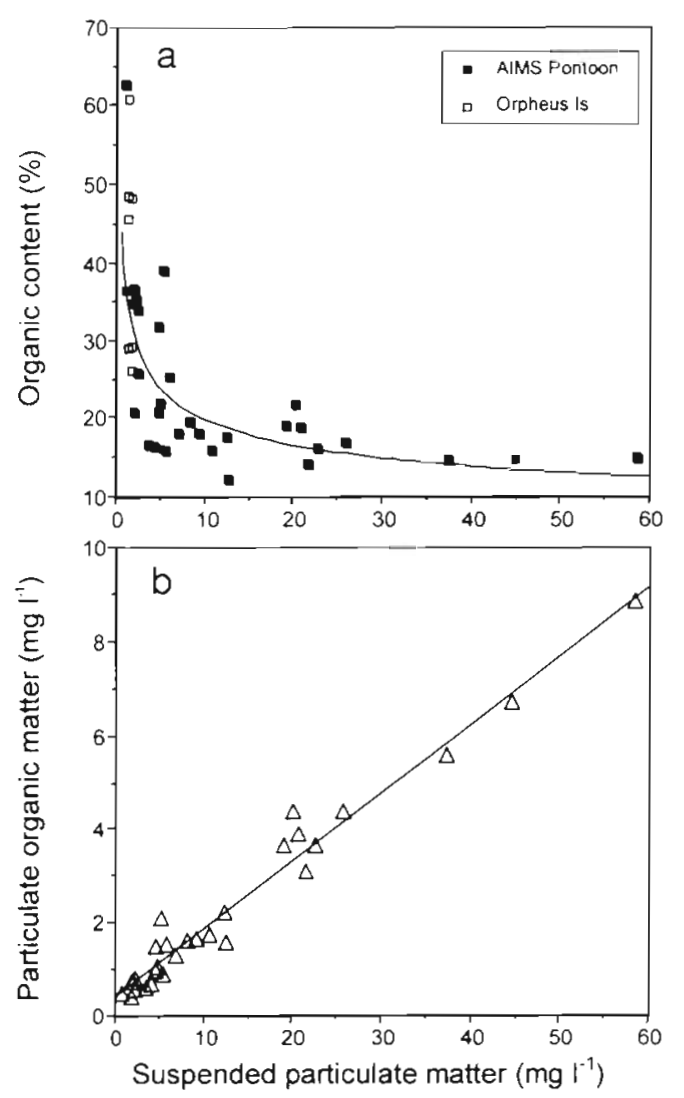

Fig. 2. (a) Organic content and (b) particulate organic matter in relation to amount of suspended particulate matter in the water column at the AIMS pontoon $(\square, \Delta)$ and at Orpheus Island $(\square, \Delta)$ (a typical habitat of Pinctada margaritifera). Regression equations are in the text

SPM concentrations and $O C(n=9)$ over a 14 mo period at Orpheus Island, a habitat of Pinctada margaritifera in the Great Barrier Reef, did not fluctuate widely, and never exceeded $2 \mathrm{mg} \mathrm{l}^{-1}$ (Fig. 2a). The relationship between OC and SPM concentration at Orpheus Island did not differ significantly (ANCOVA $\mathrm{p}>0.05$ ) from that at the AIMS experimental site over similar SPM levels ( 0.8 to $\left.3 \mathrm{mg} \mathrm{l}^{-1} ; \mathrm{n}=6\right)$. Therefore, it was assumed that conditions of low SPM (i.e. $\mathrm{SPM}<2 \mathrm{mg} \mathrm{l}^{-1}$ ) at the AIMS site approximated the natural habitat of $P$. margaritifera in terms of organic fraction.

Particulate organic matter (POM, $\mathrm{mg} \mathrm{l}^{-1}$ ) increased significantly with increasing SPM concentration (Fig. 2b):

$$
\begin{aligned}
& \mathrm{POM}=0.408+0.145 \times \mathrm{SPM} \\
& \qquad\left(\mathrm{r}^{2}=0.97, \mathrm{n}=31, \mathrm{p}<0.001\right)
\end{aligned}
$$

Thus, the increase in turbidity in the water (SPM concentration) corresponded with an increase in the absolute amounts of POM, but with a decline in the organic fraction.

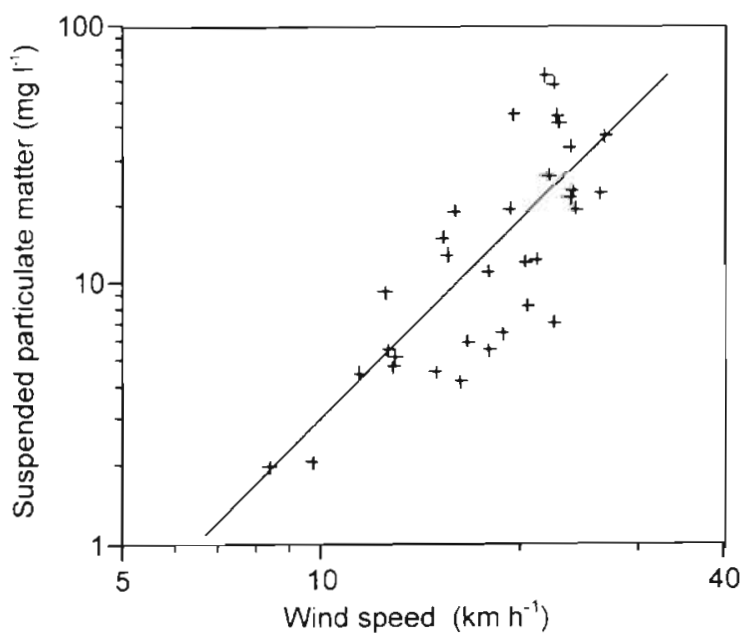

Fig. 3. Relationship between amount of suspended particulate matter in the water column and wind speed. The regression equation is in the text

The high SPM concentrations at AIMS did not coincide with spring tides and there was no major discharge from rivers. However, high SPM concentrations coincided with waves generated by strong winds (Fig. 3, $\mathrm{r}^{2}=0.61, \mathrm{n}=33, \mathrm{p}<0.001$ ). Therefore, turbid water conditions during the study period are attributable mainly to wind activity, causing resuspension of benthic materials, such as silt, benthic algae and deposited detritus.

\section{Retention efficiency}

Pinctada margaritifera and P. maxima retained particles larger than 3 and $4 \mu \mathrm{m}$, respectively, with over $90 \%$ efficiency, but the efficiencies decreased rapidly for smaller particles (Fig. 4). P. margaritifera had significantly higher retention efficiencies of particles $<3 \mu \mathrm{m}$ than P. maxima (ANOVA $\mathrm{p}<0.05$ ).

Fig. 5 shows the size composition of SPM by volume

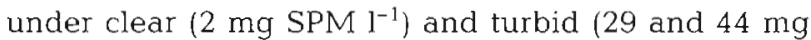
SPM $\mathrm{I}^{-1}$ ) water conditions. Turbid water tended to contain greater percentages of particles $>7 \mu \mathrm{m}$ diameter than clear water. In turbid waters of 29 and $44 \mathrm{mg} \mathrm{l}^{-1}$ SPM, 83 and $90 \%$ of particles, respectively, were larger than $4 \mu \mathrm{m}$ diameter on a volumetric basis. The clear water, in comparison, contained mainly particles smaller than $6 \mu \mathrm{m}$ and only $64 \%$ of all SPM was larger than $4 \mu \mathrm{m}$ diameter.

\section{Feeding selectivity}

Organic fractions of pseudofaeces were similar in the 2 species (Fig. 6), and there was no significant differ- 


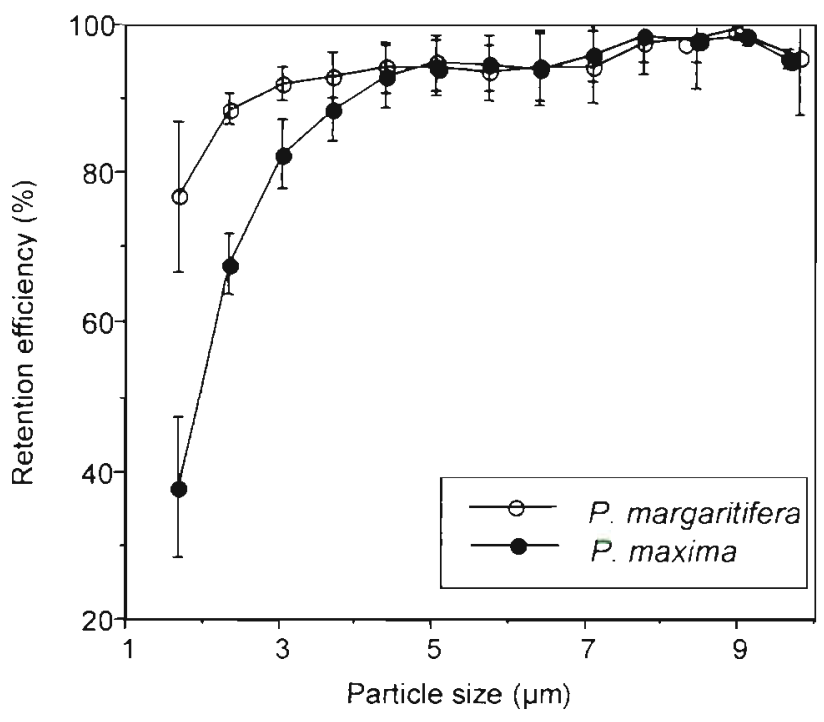

Fig. 4. Pinctada margaritifera and $P$. maxima. Retention efficiency (mean \pm SE) by oysters for different-sized particles present in the water column (SPM, $2 \mathrm{mg} \mathrm{l}^{-1}$ )

ence between the organic fraction of SPM and of pseudofaeces (ANOVA p > 0.05). This indicates that there was no feeding selectivity in either species of pearl oysters. The relationship between SPM concentration and organic fractions in pseudofaeces (OFP) of both species was identical (Table 1).

Since there were clear relationships between the $\mathrm{OC}$ and POM of natural particles and SPM concentration (Fig 2), and there was no evidence of selective feeding; hereafter, total mass of SPM was considered the food of pearl oysters. This declines in quality with increasing quantity (Fig. 2).

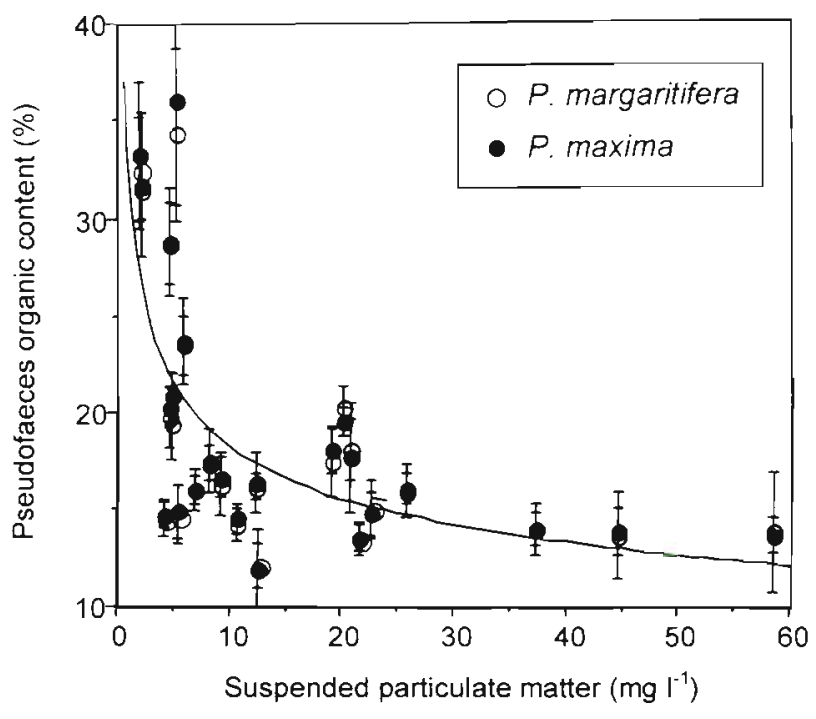

Fig. 6. Pinctada margaritifera and P. maxima. Feeding selectivity, as reflected in organic content (mean \pm SE) in pseudo faeces of oysters, at various SPM concentrations

\section{Clearance rate}

Clearance rate $\left(\mathrm{CR}, \mathrm{l} \mathrm{h} \mathrm{h}^{-1}\right)$ was significantly associated with SPM concentration, and the relationship for each species (Fig. 7) is outlined by the functions in Table 1. CR decreased with increasing SPM concentration, especially so in Pinctada margaritifera. Mean CR values for $P$. margaritifera under conditions of low SPM concentration $\left(<2.0 \mathrm{mg} \mathrm{l}^{-1}\right)$ were higher than those of P. maxima. Under turbid conditions (SPM: 12.7 to $44.7 \mathrm{mg} \mathrm{l}^{-1}$ ) the latter species always had higher $\mathrm{CR}$ (ANOVA $\mathrm{p}<0.05$ ).

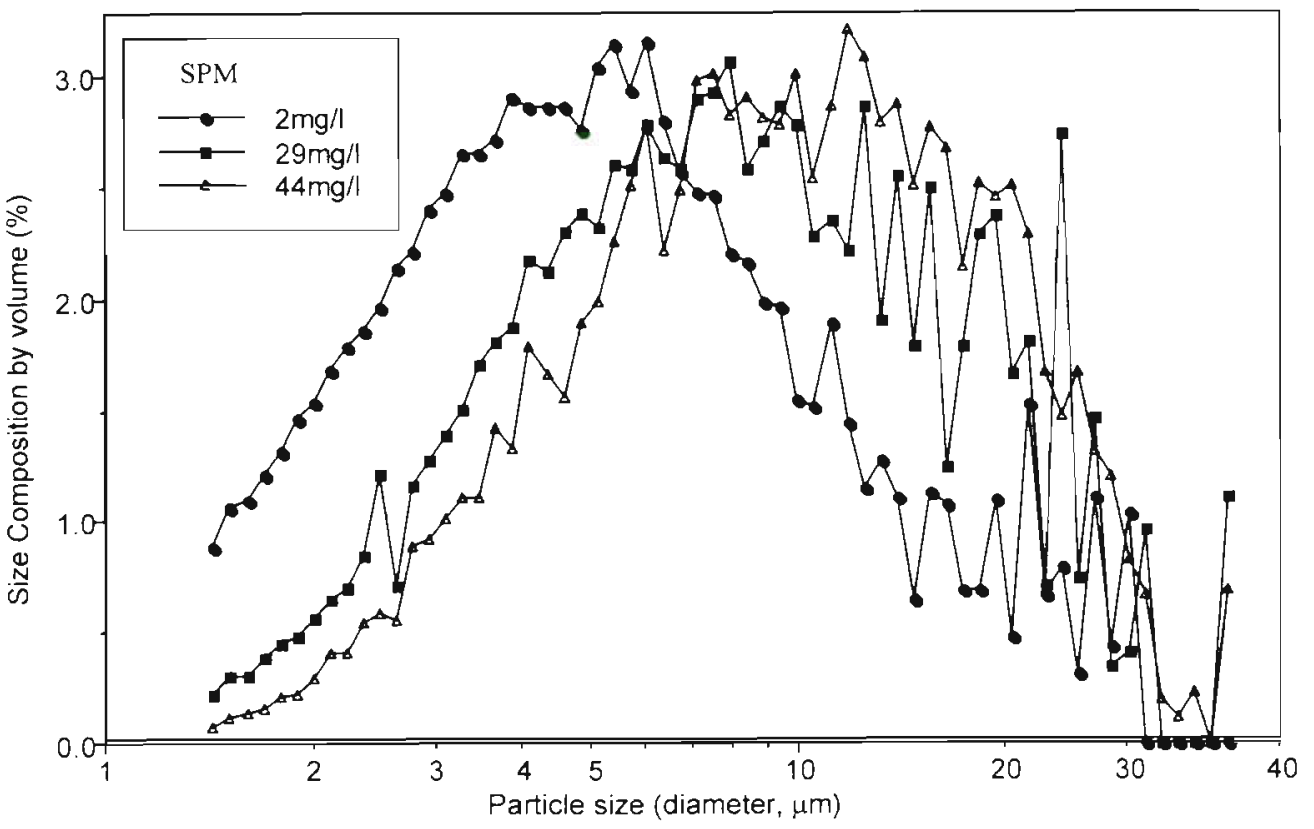

Fig. 5. Particle-size distribution in the water column at the AIMS pontoon site under different SPM conditions 
Table 1. Pinctada margaritifera and P. maxima. Relationships between feeding selectivity, clearance rate $\left(1 \mathrm{~h}^{-1}\right)$, pseudofaecal fraction (proportion of particles filtered), ingestion rate $\left(\mathrm{mg} \mathrm{h}^{-1}\right)$, absorption efficiency (\%), absorbed energy and respired energy $\left(\mathrm{J} \mathrm{h}^{-1}\right)$, and level of natural suspended particulate matter (SPM, $\left.\mathrm{mg} \mathrm{l}^{-1}\right)$; and between pseudofaeces production rate $\left(\mathrm{mg} \mathrm{h}^{-1}\right)$ and filtration rate $(F R)$

\begin{tabular}{|c|c|c|}
\hline Function & Pinctada margaritifera & Pinctada maxima \\
\hline $\begin{array}{l}\text { Feeding selectivity (organic } \\
\text { fraction in pseudofaeces, OFP) }\end{array}$ & $\begin{array}{l}\text { OFP }=0.305 S^{S} M^{-0.224} \\
\left(r^{2}=0.47, n=48, p<0.001\right)\end{array}$ & $\begin{array}{l}\mathrm{OFP}=0.305 \mathrm{SPM}^{-0.224} \\
\left(\mathrm{r}^{2}=0.47, \mathrm{n}=48, \mathrm{p}<0.001\right)\end{array}$ \\
\hline Clearance rate (CR) & $\begin{array}{l}C R=103.1 S^{S P M}-904 \\
\left(r^{2}=0.91, n=30, p<0.001\right)\end{array}$ & $\begin{array}{l}\mathrm{CR}=38.5 \times 10^{1-0.0187} \mathrm{SPMi} \\
\left(\mathrm{r}^{2}=0.95, \mathrm{n}=30, \mathrm{p}<0.001\right)\end{array}$ \\
\hline $\begin{array}{l}\text { Pseudofaeces production rate } \\
\text { (rejection rate, RR) }\end{array}$ & $\begin{array}{l}\mathrm{RR}=-29.8+0.457 \mathrm{FR} \\
\left(\mathrm{r}^{2}=0.44, \mathrm{n}=26, \mathrm{p}<0.001\right)\end{array}$ & $\begin{array}{l}\mathrm{RR}=-13.2+0.182 \mathrm{FR} \\
\left(\mathrm{r}^{2}=0.61, \mathrm{n}=24, \mathrm{p}<0.001\right)\end{array}$ \\
\hline Pseudofaecal fraction (PF) & $\begin{array}{l}P F=0.44\left(1-e^{-0.090(S P M-1.3)}\right) \\
\left(r^{2}=0.78, n=26\right)\end{array}$ & $\begin{array}{l}\mathrm{PF}=0.20\left(1-\mathrm{e}^{-0.11(\mathrm{SPM}-2.6)}\right) \\
\left(\mathrm{r}^{2}=0.73, \mathrm{n}=24\right)\end{array}$ \\
\hline Ingestion rate (IR) & $\begin{array}{l}I R=(10559 / \mathrm{SPM}) \mathrm{e}^{(-13.25 / \mathrm{SPM})} \\
\left(\mathrm{r}^{2}=0.80, \mathrm{n}=29\right)\end{array}$ & $\begin{array}{l}\mathrm{IR}=(2130 / \mathrm{SPM}) \mathrm{e}^{(-5.410 / \mathrm{SPM})} \\
\left(\mathrm{r}^{2}=0.68, \mathrm{n}=29\right)\end{array}$ \\
\hline Absorption efficiency (abs.eff.) & $\begin{array}{l}\text { abs.eff. }=0.652 \text { SPM }^{-0.340} \\
\left(r^{2}=0.83, n=29, p<0.001\right)\end{array}$ & $\begin{array}{l}\text { abs.eff }=0.630 \times 10^{-00147 \mathrm{SPM}} \\
\left(\mathrm{r}^{2}=0.92, \mathrm{n}=29, \mathrm{p}<0.001\right)\end{array}$ \\
\hline Absorbed energy (AE) & $\begin{aligned} \mathrm{AE}= & 220.5-23.8 \mathrm{SPM}+1.16 \mathrm{SPM}^{2} \\
& -0.0244 \mathrm{SPM}^{3}+0.000178 \mathrm{SPM}^{4} \\
\left(\mathrm{r}^{2}=\right. & 0.87, \mathrm{n}=29, \mathrm{p}<0.001)\end{aligned}$ & $\begin{aligned} \mathrm{AE}= & 30.2-72.0 \mathrm{SPM}-8.24 \mathrm{SPM}^{2} \\
& +0.404 \mathrm{SPM}^{3}-0.0101 \mathrm{SPM}^{4} \\
& +0.0000124 \mathrm{SPM}^{5}-0.000000602 \mathrm{SPM}^{6} \\
\left(\mathrm{r}^{2}=\right. & 0.70, \mathrm{n}=29, \mathrm{p}<0.001)\end{aligned}$ \\
\hline Respired energy (RE) & $\begin{array}{l}\left.\mathrm{RE}=70.0 S P M^{-0.159} / \pm 0.060\right) \\
\left(\mathrm{r}^{2}=0.47, \mathrm{n}=10, \mathrm{p}<0.001\right)\end{array}$ & $\begin{array}{l}\text { No significant relationship } \\
\text { with SPM }\end{array}$ \\
\hline
\end{tabular}

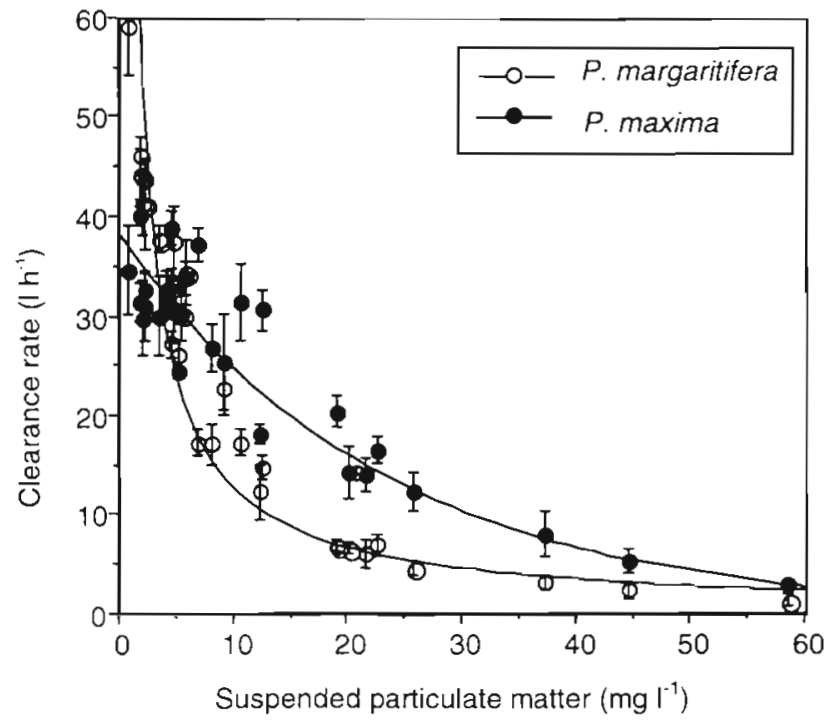

Fig. 7 Pinctada margaritifera and P. maxima. Relationships between clearance rate (mean \pm SE) of oysters and SPM concentration. Regression equations are in Table 1

\section{Pseudofaeces production}

The rejection rate $(R R, m g$ pseudofaeces ejected per h) of both species was positively associated with filtration rate ( $\mathrm{FR}=\mathrm{CR} \times \mathrm{SPM}$ concentration) (Fig. 8, Table 1). Slopes of these regression lines were signifi-

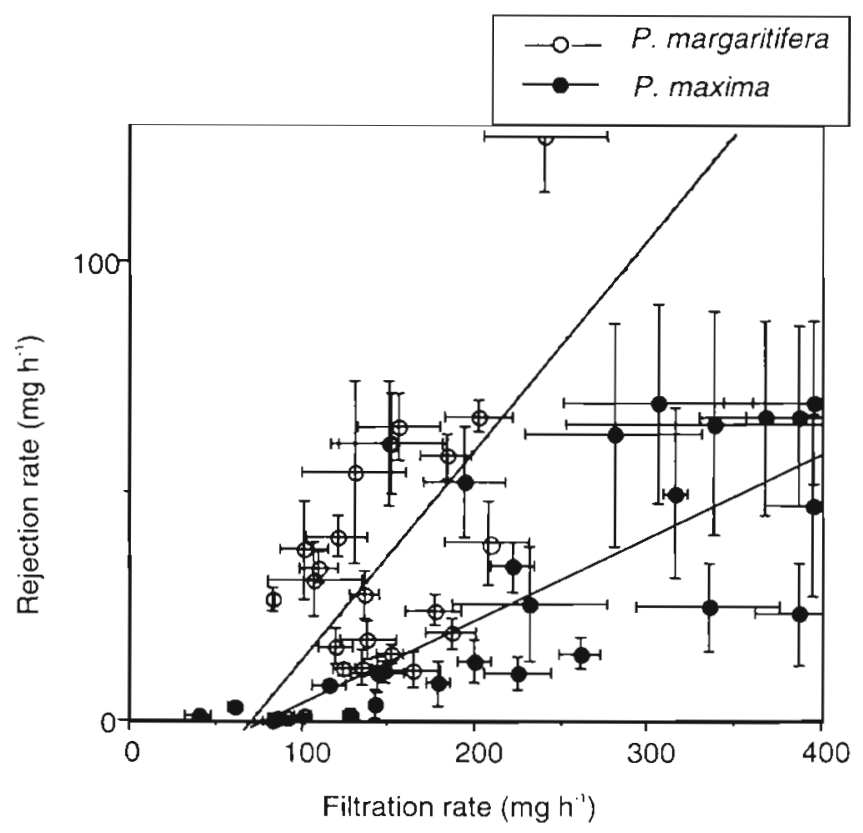

Fig. 8. Pinctada margaritifera and P. maxima. Relationships between rejection rate (mean $\pm \mathrm{SE}$ ) (pseudofaeces production rate) and filtration rate of oysters. Regression equations are in Table 1

cantly different between species (ANCOVA $\mathrm{p}<0.01$ ), indicating that Pinctada margaritifera produces significantly greater amounts of pseudofaeces for a given amount of filtered material than $P$. maxima. 


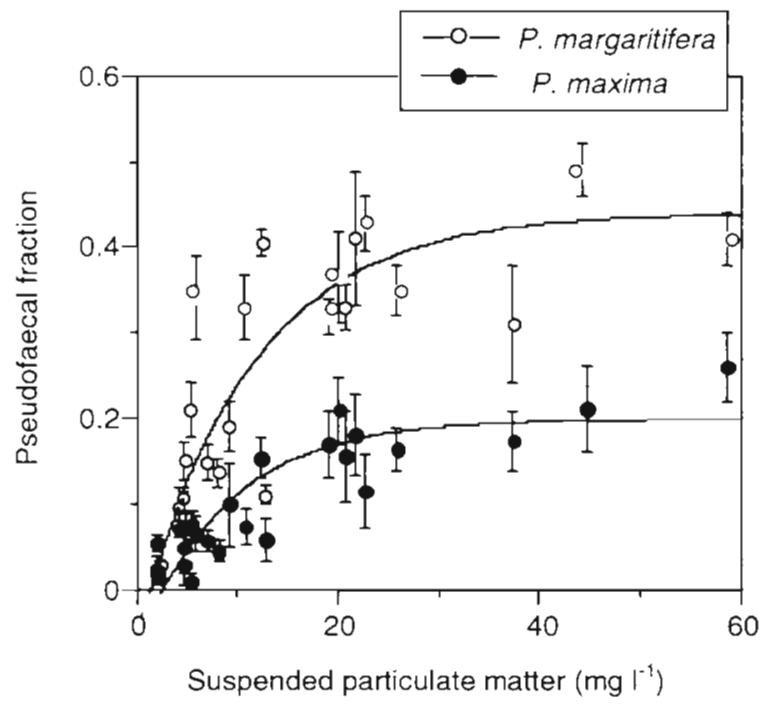

Fig. 9. Pinctada margaritifera and P. maxima. Relationships between pseudofaecal fraction (mean $\pm \mathrm{SE}$ ) in oysters and SPM concentration. Regression equations are in Table 1

The pseudofaecal fraction $(P F=R R \div F R$ ) of both species increased significantly with increasing SPM concentration (Fig 9, Table 1). The maximum pseudofaecal fraction of Pinctada margaritifera (0.4) was approximately twice that of $P$. maxima. The mean pseudofaecal fraction of the former species was significantly higher $(\mathrm{p}<0.05)$ than the latter species at SPM above $19.1 \mathrm{mg} \mathrm{l}^{-1}$.

\section{Ingestion and absorption}

Fig. 10 shows the ingestion rates ( $\mathrm{IR}, \mathrm{mg} \mathrm{h}^{-1}$ ) as a function of SPM concentration. The relationship between IR and SPM concentration for each species was expressed by the equations in Table 1 . The form of the equations is after Kiørboe et al. (1985). Pinctada margaritifera had relatively high IRs for SPM between 2 and $15 \mathrm{mg} \mathrm{l}^{-1}$ while $P$. maxima displayed high IRs over SPM of 5 to $50 \mathrm{mg} \mathrm{l}^{-1}$. IRs of $P$. maxima were consistently higher under turbid conditions (SPM $>10 \mathrm{mg} \mathrm{l}^{-1}$ ) than those of $P$. margaritifera, and the maximum IR recorded for $P$. maxima was about twice as high as that of $P$. margaritifera.

Since there was no significant difference between organic fraction of food and organic content in pseudofaeces in both species of oysters, abs.eff. was simply calculated using the Conover ratio (Conover 1966): $\because$ abs.eff. $=100(f-e) /(1-e) f$, where $f$ and $e$ are the fractions of SPM and faeces lost on ashing, respectively. The relations between abs.eff. and SPM concentration are shown in Fig. 11 \& Table 1. The abs.eff. of both species decreased with increasing SPM concen-

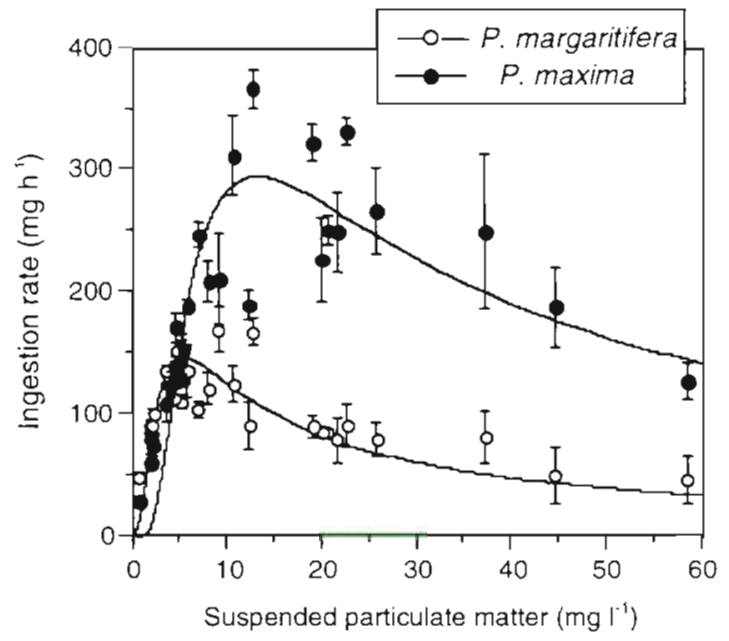

Fig. 10. Pinctada margaritifera and P. maxima. Relationships between ingestion rate (mean \pm SE) of oysters and SPM concentration. Regression equations are in Table 1

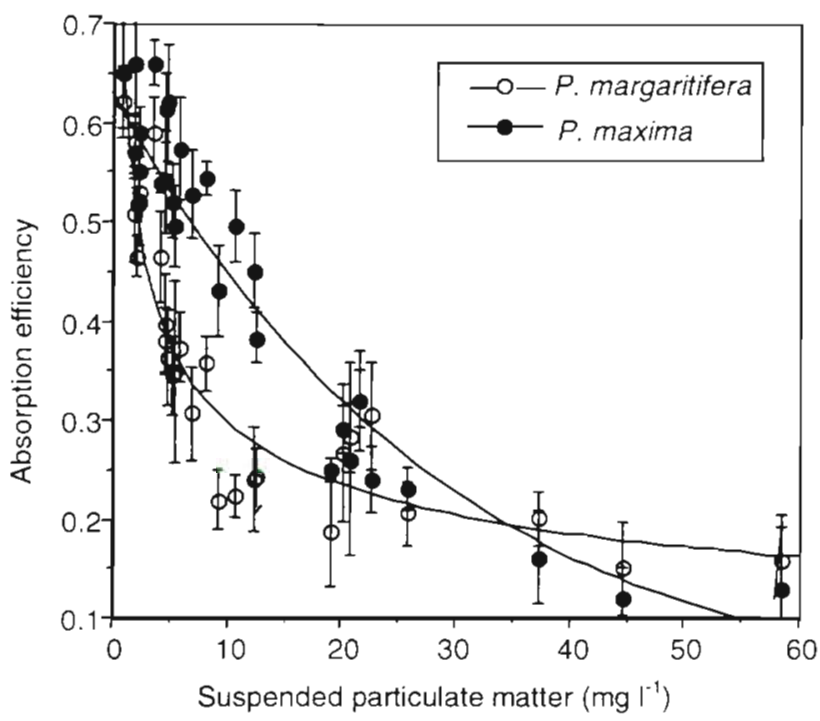

Fig 11. Pinctada margaritifera and P. maxima. Relationships between absorption efficiency (mean $\pm \mathrm{SE}$ ) in ovsters and

SPM concentration. Regression equations are in Table 1

tration. This decrease was more marked for Pinctada margaritifera. The mean abs.eff. values of $P$. maxima were consistently higher when SPM was within the range 7 to $12 \mathrm{mg} \mathrm{l}^{-1}$ (ANOVA $\mathrm{p}<0.05$ ).

The relationships between absorbed energy ( $A E$, $J h^{-1}$ ) and SPM concentration were best expressed by polynomial regressions (Fig. 12, Table 1). Pinctada maxima had maximum AE when SPM was between 5 and $15 \mathrm{mg} \mathrm{l}^{-1}$, while P. margaritifera had maximum AE for SPM below $5 \mathrm{mg} \mathrm{l}^{-1}$. The mean AE values for SPM from 5.3 to $25.8 \mathrm{mg} \mathrm{l}^{-1}$ were highest for $P$. maxima, while $P$. margaritifera had a higher mean $\mathrm{AE}$ at the 


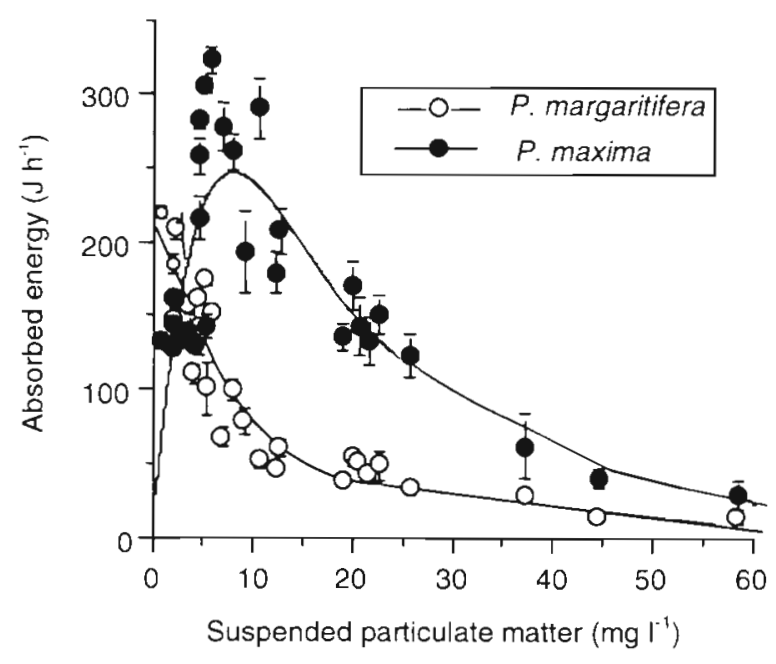

Fig. 12. Pinctada margaritifera and $P$. maxima. Relationships between absorbed energy (mean $\pm \mathrm{SE}$ ) in oysters and SPM concentration. Regression equations are in Table 1

lowest SPM concentration $10.8 \mathrm{mg} \mathrm{l}^{-1}$; ANOVA at $\mathrm{p}<$ 0.01). The predicted $A E$ and $95 \%$ confidence limits (CL) in response to different SPM conditions were calculated using the equations and are shown in Table 2.

Table 2. Pinctada margaritifera and $P$. maxima. Calculated mean values $\pm 95 \%$ confidence limits of absorbed energy (AE), respired energy (RE), excreted energy $(\mathrm{EE})$ and resultant scope for growth $(\mathrm{SFG}=\mathrm{AE}-\mathrm{RE}-\mathrm{EE}$ ) of oysters in relation to different levels of suspended particulate matter

\begin{tabular}{|c|c|c|c|c|c|c|c|c|c|}
\hline & \multirow[t]{2}{*}{ Species } & \multicolumn{8}{|c|}{$\operatorname{SPM}\left(\mathrm{mg} \mathrm{l}^{-1}\right)$} \\
\hline & & 3 & 5 & 7 & 10 & 15 & 20 & 30 & 40 \\
\hline \multirow{6}{*}{$\begin{array}{l}\mathrm{AE} \\
\left(\mathrm{J} \mathrm{h}^{-1}\right)\end{array}$} & \multirow{3}{*}{ P. margaritifera } & 158 & 127 & 103 & 76 & 53 & 47 & 41 & 24 \\
\hline & & 143 & 114 & 88 & 59 & 37 & 28 & 15 & -11 \\
\hline & & 173 & 140 & 118 & 93 & 69 & 66 & 67 & 58 \\
\hline & \multirow[t]{3}{*}{ P. maxima } & 180 & 227 & 245 & 240 & 194 & 150 & 99 & 55 \\
\hline & & 150 & 1.97 & 215 & 201 & 147 & 111 & 24 & -31 \\
\hline & & 210 & 259 & 277 & 280 & 241 & 190 & 175 & 142 \\
\hline \multirow{6}{*}{$\begin{array}{l}\text { RE } \\
\left(\mathrm{J} \mathrm{h}^{-1}\right)\end{array}$} & \multirow{3}{*}{ P. margaritifera } & 59 & 54 & 51 & 49 & 46 & 43 & 41 & 39 \\
\hline & & 46 & 41 & 38 & 35 & 32 & 30 & 28 & 26 \\
\hline & & 73 & 69 & 67 & 65 & 62 & 61 & 58 & 57 \\
\hline & \multirow[t]{3}{*}{ P. maxima } & 65 & 65 & 65 & 65 & 65 & 65 & 65 & 65 \\
\hline & & 52 & 52 & 52 & 52 & 52 & 52 & 52 & 52 \\
\hline & & 78 & 78 & 78 & 78 & 78 & 78 & 78 & 78 \\
\hline $\begin{array}{l}\text { EE } \\
\left(\mathrm{J} \mathrm{h}^{-1}\right)\end{array}$ & Both species & 6 & 6 & 6 & 6 & 6 & 6 & 6 & 6 \\
\hline \multirow{6}{*}{$\begin{array}{l}\text { SFG } \\
\left(\mathrm{J} \mathrm{h}^{-1}\right)\end{array}$} & \multirow{3}{*}{ P. margaritifera } & 94 & 67 & 46 & 22 & 2 & -2 & -5 & -21 \\
\hline & & 64 & 39 & 15 & -12 & -31 & -38 & -49 & -73 \\
\hline & & 121 & 93 & 74 & 52 & 31 & 30 & 34 & 26 \\
\hline & \multirow[t]{3}{*}{ P. maxima } & 109 & 156 & 174 & 169 & 123 & 79 & 28 & -16 \\
\hline & & 66 & 113 & 131 & 117 & 63 & 27 & -60 & -115 \\
\hline & & 152 & 201 & 219 & 222 & 183 & 132 & 117 & 84 \\
\hline
\end{tabular}

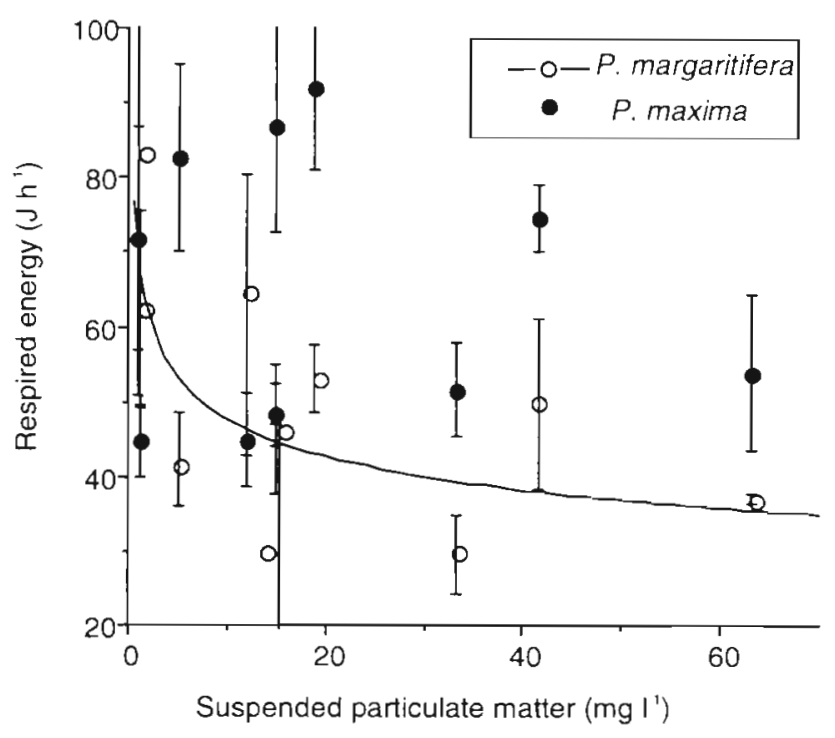

Fig. 13. Pinctada margaritifera and P. maxima. Relationships between respired energy (mean \pm SE) in oysters and SPM concentration. Regression equation is in Table 1

\section{Respiration}

Respired energy (RE, $\mathrm{J} \mathrm{h}^{-1}$ ) of Pinctada maxima did not vary with SPM concentration, but RE of $P$. margaritifera decreased significantly with increasing SPM concentration (Fig. 13, Table 1). Using this regression, predicted RE values and 95\% CLs of P. margaritifera in response to different SPM concentrations were calculated (Table 2). The mean RE value $\pm 95 \% \mathrm{CL}$ for $P$. maxima was $65.1 \pm$ $13.2 \mathrm{~J} \mathrm{~h}^{-1}(\mathrm{n}=10)$ over all SPM levels.

\section{Excreted energy}

Excreted energy $\left(\mathrm{EE}, \mathrm{J} \mathrm{h} \mathrm{h}^{-1}\right.$ ) in both pearl oyster species was not affected by SPM concentration (Fig. 14). There was no significant difference in mean $E E$ between the 2 species (ANOVA p >0.05). Therefore, all EE values were pooled and a common mean value $( \pm 95 \% \mathrm{CL}$ ) was calculated for both species $(5.83 \pm 0.65 \mathrm{~J}$ $\mathrm{h}^{-1}, \mathrm{n}=26$ ).

\section{Scope for growth}

Table 2 shows the calculated scope for growth $\left(\mathrm{SFG}=\mathrm{AE}-\mathrm{RE}-\mathrm{EE}, \mathrm{J} \mathrm{h}^{-1}\right)$. Pinc- 


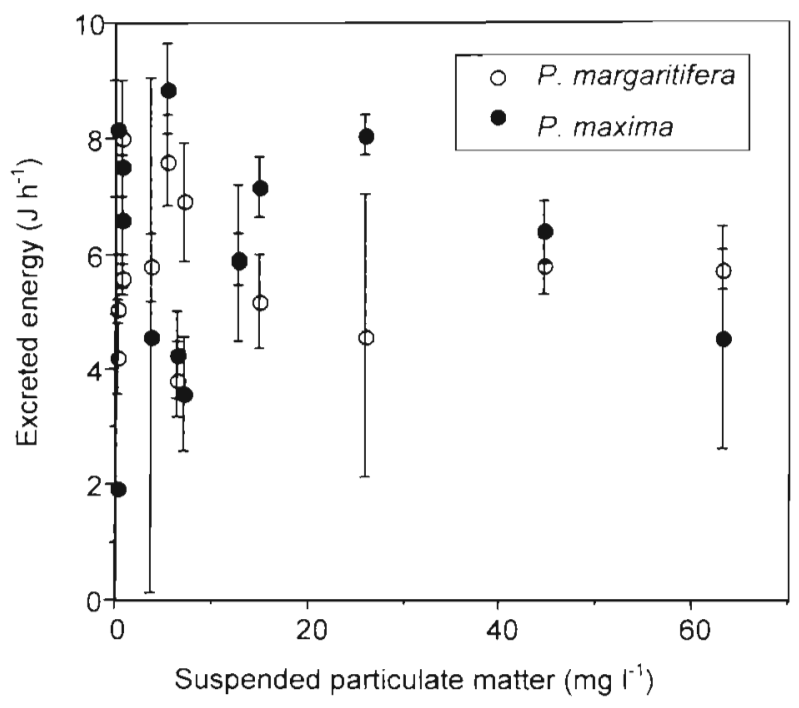

Fig. 14. Pinctada margaritifera and P. maxima. Excreted energy (mean $\pm \mathrm{SE}$ ) in oysters in relation to SPM concentration

tada margaritifera had a high mean SFG at low SPM concentration (< ca $3 \mathrm{mg} \mathrm{l}^{-1}$ ), but mean SFG fell to zero at ca 10 to $20 \mathrm{mg} \mathrm{l}^{-1}$. P. maxima had highest mean SFG at ca $10 \mathrm{mg} \mathrm{SPM} \mathrm{l}^{-1}$ and maintained positive values of $\mathrm{SFG}$ up to $40 \mathrm{mg} \mathrm{l}^{-1}$. Considering lower and upper $95 \%$ $\mathrm{CL}$ values for $\mathrm{AE}$ and $\mathrm{RE}, \mathrm{SFG}$ of $P$. maxima was always higher than $P$. margaritifera over the SPM concentration range of 5 to $15 \mathrm{mg} \mathrm{l}^{-1}$.

\section{DISCUSSION}

Feeding and food utilisation in the pearl oysters Pinctada margaritifera and $P$. maxima were affected by variations in both quantity and quality of natural SPM. Oysters responded to increases in turbidity (SPM concentration), and corresponding declines in the quality of particulates (lowered organic fraction) by reducing their $C R$, and absorption efficiency, and by increasing the PF. Comparing both species, $P$. maxima had higher $C R$, ingestion rate, food absorption and lower $P F$, and thus greater AE under a wide range of field conditions. Of the 2 species, P. maxima is clearly a more efficient suspension feeder at high concentrations of SPM.

Similarly, when feeding on pure algal diets, Pinctada maxima was more efficient than $P$. margaritifera at gaining energy at high cell concentrations (Yukihira et al. 1998b). However, there were several differences between the feeding and energy budgets of pearl oysters supplied with mono-specific algal diets (Yukihira et al. 1998a,b) and those fed natural SPM. For example, SFG was much higher on the natural diet at all particle concentrations, and also the thresholds of particulate
Table 3. Pinctada margaritifera and P. maxima. Threshold concentration ( $\mathrm{mg} \mathrm{l}^{-1}$ ) above which the scope for growth of oysters falls below zero when feeding on 2 microalgal diets, Dunaliella primolecta and Tahitian Isochrysis galbana (T-Iso), and natural suspended particulate matter (SPM). (Data for the microalgal diets from Yukihira et al. 1998b

\begin{tabular}{|lccc|}
\hline & D. primolecta & T-Iso & SPM \\
\hline P. margaritifera & 5 & 7 & $1.0-20$ \\
P. maxima & 7 & 9 & $30-40$ \\
\hline
\end{tabular}

concentrations above which SFG fell below zero were far higher on the natural diet than on cultured algal diets (Table 3). These differences result from higher CR and food absorption, and lower PF under conditions of high SPM concentration. The results agree with the conclusions reached by Griffiths (1980b), Riisgård (1991) and Jorgensen (1996) for mytilids. One reason for the difference suggested by Griffiths (1980b) might be that cultured algal diets are extremely concentrated food resources that are never experienced in natural habitats (natural SPM includes substantial inorganic fraction) and this adversely affects feeding functions (i.e. filtration, pseudofaeces production and absorption). The comparatively high SFG we observed for pearl oysters fed natural particles may also be due to the presence of inorganic particles. Griffiths (1980b) and Navarro et al. (1996) reported that particulate inorganic matter enhanced absorption of algal food. Similarly, Urban \& Langdon (1984) demonstrated that the addition of kaolinite to algae/ yeast diets improved oyster growth. Jørgensen (1990) showed that the presence of silt in a microalgal diet resulted in higher growth rate of Mytilus edulis.

A number of temperate and tropical bivalve species have been found to selectively ingest organic material and reject inorganic or unfavourable material in the pseudofaeces to cope with high fractions of inorganic particles in turbid water conditions (Navarro et al. 1992, Bayne et al. 1993, Hawkins et al. 1996, 1998, Barillé et al. 1997). However, there was no evidence of selective feeding on organic particles as a pre-ingestive strategy in either Pinctada margaritifera or $P$. maxima. This was also demonstrated in the sub-tropical pearl oyster P. imbricata (Ward \& MacDonald 1996) and in $P$. margaritifera in Malaysia (Hawkins et al. 1998). On the basis of gut analysis, Gervis \& Sims (1992) have also suggested an absence of food selection in Pinctada species. Low feeding rates are generally associated with more efficient processes of particle selection (Sierszen \& Frost 1992, MacDonald \& Ward 1994, Ward \& MacDonald 1996). P. margaritifera and $P$. maxima have relatively high pumping rates compared with other bivalve species (Yukihira et al. 1998a). 
Thus, the lack of selective feeding may be at least partially explained by their high CR. Some anatomical features, such as gill and labial palp structures may also be associated with non-selective feeding of these species. Adaptation of $P$. maxima to relatively turbid environments appears to be explained by its greater ingestion rate and higher digestibility.

Even though SPM in inshore waters includes a substantial fraction of inorganic matter, these waters are high in particulate organic matter (POM). This is a potentially rich source of food to filter feeders such as Pinctada maxima. By contrast, in oligotrophic coral reef waters, neither SPM nor POM are abundant. However, P. margaritifera filters smaller particles more efficiently than $P$. maxima, and filters particles larger than $3 \mu \mathrm{m}$ at high efficiencies (>90\%) under conditions of low SPM concentration ( $2 \mathrm{mg}^{-1}$ ). Dufour \& Torréton (1996) also found that $P$. margaritifera was able to filter particles smaller than $3 \mu \mathrm{m}$, and they suggested that this species uses bacterial aggregates as a supplemental food source. Small particles were dominant in clear water conditions $\left(<2 \mathrm{mg}\right.$ SPM $\left.\mathrm{l}^{-1}\right)$ compared to turbid conditions at the 2 Great Barrier Reef sites of this study. Similarly, EVAAM (1996, cited by Anonymous 1997) reported that POM in Takapoto Lagoon, French Polynesia, a habitat of $P$. margaritifera, consisted predominantly $(75 \%)$ of particles less than $3 \mu \mathrm{m}$. In Takapoto Lagoon there was no seasonal pattern of variation in the quantity of SPM: it varied according to water agitation from wind and swell and increased by $54 \%$ when the lagoon waters were disturbed. Taken overall, the capability of filtering smaller sized food particles for $P$. margaritifera may be a vital adaptation to maximise energy gain in environments of low SPM concentration.

Differences in patterns of energy gain and consumption between the 2 species relate well to differences in their habitats. Pinctada maxima feeds most efficiently and thus gains the greatest energy from natural SPM under relatively turbid conditions: particularly within the SPM range of ca 3 to $15 \mathrm{mg} \mathrm{l}^{-1}$ (Table 2). Adult $P$. maxima detach their byssal threads and come to rest on the substratum where the environment is characterised by high amounts of terrigenous sediments, nutrient inputs, high productivity levels and fast water currents (Gervis \& Sims 1992). Grant et al. (1990) suggested that resuspended bottom material could be a valuable food supplement for cultured bivalves, and a positive relationship between bivalve growth and food particles supplied from the benthos has been reported for Macoma balthica (Thompson \& Nichols 1988), Mytilus edulis (Rhoads et al. 1984) and Ostrea edulis (Grant et al. 1990). While a severe reduction in food quality due to wind-driven resuspension was observed in this study, the absolute amount of POM steadily increased as water became turbid. Its habitats and feeding responses under turbid conditions indicate that $P$. maxima uses resuspended sediments as valuable additional food, and potentially grows and reproduces even under relatively high turbidity conditions (up to SPM concentrations of ca 30 to $40 \mathrm{mg} \mathrm{l}^{-1}$ ). In contrast, P. margaritifera maximises energy gain under low SPM concentrations $\left(<3 \mathrm{mg} \mathrm{l}^{-1}\right)$, which represent conditions of coral reef waters, and which coincided very well with SPM concentrations observed in a typical natural habitat of $P$. margaritifera (1 to $2 \mathrm{mg} \mathrm{l}^{-1}$ at Orpheus Island).

Comparing feeding behaviour in 5 tropical bivalve molluscs supplied with natural seston in a relatively turbid mangrove estuary, Hawkins et al. (1998) concluded that Pinctada margaritifera had the lowest rate of absorption from POM. SPM varied from 10 to $23 \mathrm{mg}$ $\mathrm{I}^{-1}$ during their short-term study of $P$. margaritifera; however, our findings show these are the least optimal conditions for efficient energy acquisition in this species. In its optimal environment, such as on coral reefs $\left(<3 \mathrm{mg} \mathrm{l}^{-1}\right)$, P. margaritifera should absorb some 3 to 4 times more energy from POM than in turbid waters (see AE data in Table 2). Hawkins et al. (1998) also suggested that the low nutrient acquisition they observed for $P$. margaritifera was a partial explanation for slow growth in the Pinctada group. They based this hypothesis on growth data for the Japanese pearl oyster $P$. fucata martensii. In comparison, tropical pearl oysters such as $P$. margaritifera are fast-growing bivalves (Gervis \& Sims 1992, Yukihira 1998, see 'Introduction').

Studies of physiological energetics in mussels have demonstrated that SFG over a wide food concentration range corresponds well with measured growth and reproductive output (Bayne \& Worral 1980, van Erkom Schurink \& Griffiths 1992). Of the 2 pearl oysters, Pinctada maxima reaches a larger size in terms of both shell length and soft tissue. The maximum body size (including byssal threads) recorded for $P$. maxima and $P$. margaritifera in these studies was 27 and $19 \mathrm{~g}$ soft tissue dry wt, respectively (Yukihira 1998). Given that the SFG values in this study were calculated for $10 \mathrm{~g}$ tissue dry wt oysters, and both oyster species are sexually mature at this size, the greater maximum SFG recorded for $P$. maxima suggests why it grows to a larger body size.

This study provides information that may be used for ecologically sustainable developments in the rapidly expanding pearl oyster industry. In general, suspension feeding activities by cultured bivalves under conditions of slow water exchange tend to cause depletion of natural food particles (Newell 1990, Fréchette \& Grant 1991, Navarro et al. 1991, Grant 1996) and affect bottom environments due to biodeposition of faeces 
and pseudofaeces from the bivalves (Kusuki 1977 , 1978, Kaspar et al. 1985, Baudinet et al. 1990. DeslousPaoli et al. 1992, Bacher et al. 1995, Gilbert et al. 1997). Consequently, intensive bivalve aquaculture may have substantial environmental impacts on local ecosystems (Ito \& Imai 1955, Kusuki 1977, 1978, Hatcher et al. 1994, Bacher et al. 1995, Kishi \& Uchiyama 1995).

There have been several cases of environmental degradation associated with pearl culture. Recent mass mortalities of the Japanese pearl oyster Pinctada fucata martensii in culture grounds of Japan were due to the synergistic effects of dense culture and environmental degradation (e.g. harmful red tides), (Nagai et al. 1996 , Shinomiya et al. 1997, Tanaka 1997). Similarly, mass mortalities of the tropical black-lip pearl oyster P. margaritifera during 1985 to 1986 in Takapoto lagoon, French Polynesia (Vacelet et al. 1996, Charpy et al. 1997) were attributed to the depletion of natural food particles by densely cultured $P$. margaritifera.

Both Pinctada margaritifera and $P$. maxima maintain high feeding rates over a wide range of environmental conditions (Yukihira 1998): their ecological roles in energy transfer and environmental impacts on ecosystems as suspension feeders can be of considerable importance. Therefore the stocking densities of cultured pearl oysters should be managed, taking account of water replacement conditions. Before launching pearl farming in an area, it would be wise to conduct trophic modelling and environmental impact assessment at the appropriate stocking densities of cultured pearl oysters, as has been undertaken for mussel farming (e.g. Rodhouse \& Roden 1987, Grant 1996).

Acknowledgements. We thank Mr Michael Crimp of IndoPacific Pearl for providing the pearl oysters. This research was funded by an Internal Research Allowance and a Meritorious Research Grant from James Cook University.

\section{LITERATURE CITED}

Anonymous (1997) The French Polynesian multidisciplinary pearl oyster research programme (PGRN) publishes phase I results. In: Sims N (ed) Pearl oyster no. 10. South Pacific Commission, Noumea, New Caledonia, p 6

Bacher C, Bioteau H, Chapelle A (1995) Modelling the impact of a cultivated oyster population on the nitrogen dynamics: the Thau lagoon case (France). Ophelia 42:29-54

Barillé L, Prou J, Héral M, Razet D (1997) Effects of high natural seston concentrations on the feeding selection and absorption of the oyster Crassostrea gigas (Thunberg). J Exp Mar Biol Ecol 212:149-172

Baudinet D, Alliot E, Berland B, Grenz C, Plante-Cuny MR, Plante R, Salen-Picard C (1990) Incidence of mussel culture on biogeochemical fluxes at the sediment-water interface. Hydrobiol 207:187-196

Bayne BL, Worral CM (1980) Growth and production of mussels (Mytilus edulis) from two populations. Mar Ecol Prog Ser 3:317-28
Bayne BL, Brown DA, Burns $K$, Dixon DR, Ivanovici $A$, Livingstone DR, Lowe DM, Moore MN, Stebbing ARD, Widdows J (1985) The effects of stress and pollution on marine animals. Chap 1, Physiological measurements and Chap 7 Physiological procedures. Praeger Press, New York, p 4-45, 161-171

Bayne BL, Iglesias JIP, Hawkins AJS, Navarro E, Heral M. Deslous-Paoli JM (1993) Feeding behaviour of the mussel Mytilus edulis: responses to variation in quantity organic content of the seston. J Mar Biol Assoc UK 73:813-829

Charpy L, Dufour P, Garcia N (1997) Particulate organic matter in sixteen Tuamotu atoll lagoons (French Polynesia) Mar Ecol Prog Ser 151:55-65

Conover RJ (1966) Assimilation of organic matter by zooplankton. Limnol Oceanogr 18:673-678

Deslous-Paoli JM, Lannou AM, Geairon P, Bougrier S, Raillard O, Héral M (1992) Effects of the feeding behaviour of Crassostrea gigas (bivalve molluscs) on biosedimentation of natural articulate matter. Hydrobiol 231:85-91

Dufour P, Torréton JP (1996) Utilization of bacterioplankton as a food source by the pearl oyster Pinctada margaritifera. In: Lessios HA (ed) Proc 8th Int Coral Reef Symp Panama, Abstracts. Smithsonian Tropical Research Institution, Balboa, p 54

EVAAM (1996) Te Reko Parau, no. 5, October 1996. Etablissement pour la valorisation des activités aquacoles et maritimes (EVAAM), Tahiti, French Polynesia

Fréchette M, Grant J (1991) An in situ estimation of the effect of wind-driven resuspension on the growth of the mussel Mytilus edulis L. J Exp Mar Biol Ecol 1.48:201-203

Gervis MH. Sims NA (1992) The biology and culture of pearl oysters (Bivalvia: Pterijdae). ICLARM Stud Rev 21

Gilbert F, Souchu P, Bianchi M, Bonin P (1997) Influence of shellfish farming activities on nitrification, nitrate reduction to ammonium and denitrification at the water-sediment interface of the Thau lagoon. France. Mar Ecol Prog Ser 151:143-153

Grant J (1996) The relationship of bioenergetics and the environment to the field growth of cultured bivalves. J Exp Mar Biol Ecol 200:239-256

Grant J, Enright CT, Griswold A (1.990) Resuspension and growth of Ostrea edulis: a field experiment. Mar Biol 104:51-59

Griffiths RJ (1980a) Filtration, respiration and assimilation in the black mussel Choromytilus meridionalis. Mar Ecol Prog Ser 3:63-70

Griffiths RJ (1980b) Natural food availability and assimilation in the bivalve Choromytilus meridionalis. Mar Ecol Prog Ser 3:151-156

Hatcher A, Grant J, Schofield B (1994) Effects of suspended mussel culture (Mytilus spp) on sedimentation, benthic respiration and sediment nutrient dynamics in a coastal bay. Mar Ecol Prog Ser 115:219-235

Hawkins AJS, Smith RFM, Bayne BL, Héral M (1996) Novel observations underlying the fast growth of suspensionfeeding shellfish in turbid environments: Mytilus edulis. Mar Ecol Prog Ser 131:179-190

Hawkins AJS, Smith RFM, Tan SH, Yasin ZB (1998) Suspension feeding behaviour in tropical bivalve molluscs: Perna viridis, Crassostrea belcheri, Crassostrea iradelei, Saccostrea cucculata and Pinctada margarifera. Mar Ecol Prog Ser 166:173-185

Ito S, Imai T (1955) Ecology of oyster bed I: on the decline of productivity due to repeated culture. Tohoku J Agric Res $5: 251-268$

Jargensen CB (1990) Bivalve filter feeding: hydrodynamics, bioenergetics, physiology and ecology. Olsen \& Olsen, Fredensborg 
Jørgensen CB (1996) Review: bivalve filterfeeding revisited Mar Ecol Prog Ser 141:287-302

Kailola PJ, Williams MJ, Stewart PC, Reichelt RE, McNee A Grieve C (1993) Australian fisheries resoutces. Bureau of Resource Sciences, Department of Primary Industries and Energy, and the Fisheries Research and Development Corporation, Canberra, p 87-89

Kaspar HF, Gillespie PA, Boyer IC, Mackenzie AL (1985) Effects of mussel aquaculture on the nitrogen cycle and benthic communities in Kenepuru Sound, Marlborough Sounds, New Zealand. Mar Biol 85:127-136

Kiørboe T, Mohlenberg F, Hamburger K (1985) Bioenergetics of the planktonic copepod Acartia tonsa: relation between feeding, egg production and respiration, and composition of specific dynamic action. Mar Ecol Prog Ser 26:85-97

Kishi M, Uchiyama M (1995) A three-dimensional numerical model for a mariculture nitrogen cycle: case study in Shizugawa Bay, Japan. Fish Oceanogr 4:303-316

Klumpp DW, Bayne BL, Hawkins AJS (1992) Nutrition of the giant clam Tridacna gigas (L). I. Contribution of filter feeding and photosynthates to respiration and growth. J Exp Mar Biol Ecol 155:105-122

Kusuki Y (1977) Fundamental studies on the deterioration of oyster grazing grounds II: organic content of faecal materials. Bull Jpn Soc Sci Fish 43:167-171 (in Japanese)

Kusuki Y (1978) Relationship between quantities of faecal material produced and quantities of the suspended matter removed by the Japanese oyster. Bull Jpn Soc Sci Fish 44: 1183-185 (in Japanese)

MacDonald BA, Ward JE (1994) Variation in food quality and particle selectivity in the sea scallop Placopecten magellanicus (Mollusca: Bivalvia). Mar Ecol Prog Ser 108: $251-264$

Nagai K, Matsuyama $Y$, Uchida T, Yamaguchi M, Ishimura M, Nishimura A, Akamatsu S, Honjo T (1996) Toxicity and $\mathrm{LD}_{50}$ levels of the red tide dinoflagellate Heterocapsa circularisquama on juvenile pearl oysters. Aquaculture 144: $149-154$

Navarro JM, Widdows J (1997) Feeding physiology of Cerastoderma edule in response to a wide range of seston concentrations. Mar Ecol Prog Ser 152:175-186

Navarro E, Iglesias JIP, Pérez Camacho A, Labarta U, Beiras R (1991) The physiological energetics of mussels (Mytilus galloprovincialis Lmk) from different cultivation rafts in the Ria de Arosa (Galicia, NW Spain). Aquaculture 94: $197-212$

Navarro E, Iglesias JIP, Ortega MM (1992) Natural sediment as a food source for the cockle Cerastoderma edule (L) effect of variable particle concentration on feeding, digestion and the scope for growth. J Exp Mar Biol Ecol 156: $69-87$

Navarro E, Iglesias JIP, Pérez Camacho A, Labarta U (1996) The effect of diet of phytoplankton and suspended bottom material on feeding and absorption of raft mussels (Mytilus galloprovincialis Lmk). J Exp Mar Biol Ecol 198:175-189

Newell CR (1990) The effects of mussel (Mytilus edulis, Linnaeus 1758 ) position in seeded bottom patches on growth at subtidal lease sites in Maine. J Shellfish Res 9:113-118

Rhoads DC, Boyer LF, Welsh BL, Hampson GR (1984) Seasonal dynamics of detritus in the benthic turbidity zone (BTZ): implications for bottom-rack molluscan mariculture. Bull Mar Sci 35:536-549

Riisgård HU (1991) Filtration rate and growth in the blue mus- sel, Mytilus edulis Linnaeaus, 1758: dependence on algal concentration. J Shellfish Res 10:29-35

Rodhouse P. Roden CM (1987) Carbon budget for a coastal inlet in relation to intensive cultivation of suspensionfeeding bivalve molluscs. Mar Ecol Prog Ser 36:225-236

Shinomiya Y, Iwanaga S, Yamaguchi T, Kohno K, Uchimura Y (1997) Relationship between autumn mortality, glycogen content, and carbohydrate metabolism enzyme activity in Japanese pearl oyster Pinctada fucata martensii. Suisan Zoshoku 45:47-53 (in Japanese)

Sierszen ME, Frost TM (1992) selectivity in suspension feeders: food quality and the cost of being selective. Arch Hydrobiol 123:257-273

Sims NA (1992) Abundance and distribution of the black-lip pearl oyster, Pinctada margaritifera (L.), in the Cook Islands, South Pacific. Aust J Mar Freshw Res 43: $1409-1421$

Sims NA (1993) Size, age and growth of the black-lip pearl oyster, Pinctada margantifera (L.) (Bivalvia; Pteriidae). J Shellfish Res 12:223-228

Solorzano L (1969) Determination of ammonia in natural waters by the phenol-hypochlorite method. Limnol Oceanogr 14:199-801

Tanaka K (1997) Food environment in pearl culture grounds No1: diagnosis of culture ground environment using nutritive salts concentration. Yoshoku, Midori Shobo, Tokyo, p 109-112 (in Japanese)

Thompson JK, Nichols FH (1988) Food availability controls seasonal cycle of growth in Macoma balthica (L) in San Francisco Bay, California. J Exp Mar Biol Ecol 116:43-61

Urban ER, Langdon CJ (1984) Reduction in costs of diets for the American oyster Crassostrea virginica (Gmelin), by the use of non-algal supplements. Aquaculture 38: $277-291$

Vacelet E, Arnoux A, Thomassin B (1996) Particulate material as an indicator of pearl-oyster excess in the Takapoto lagoon (Tuamotu, French Polynesia). Aquaculture 144: $133-148$

van Erkom Schurink C, Griffiths CL (1992) Physiological energetics of four South African mussel species in relation to body size, ration and temperature. Comp Biochem Physiol 101A:779-789

Ward JE, MacDonald BA (1996) Pre-ingestive feeding behaviors of two sub-tropical bivalves (Pinctada imbricata and Arca zebra): responses to an acute increase in suspended sediment concentration. Bull Mar Sci 59:417-432

Warren CE, Davis GE (1967) Laboratory studies on the feeding, bioenergetics, and growth of fish. In: Gerking SD (ed) The biological basis of freshwater fish production. Blackwell Scientific Publications, Oxford, p 175-214

Yukihira H (1998) Feeding, energy budgets and nutritional ecology of the pearl oysters, Pinctada margaritifera (Linnaeus) and $P$. maxima. PhD thesis, James Cook University, Townsville

Yukihira H, Klumpp DW, Lucas JS (1998a) Effects of body size on suspension feeding and energy budgets of the pearl oysters Pinctada margaritifera and P. maxima. Mar Ecol Prog Ser 170:119-130

Yukihira H, Klumpp DW, Lucas JS (1998b) Comparative effects of microalgal species and food concentration on suspension feeding and energy budgets of the pearl oysters Pinctada margaritifera and P. maxima (Bivalvia: Pteriidae). Mar Ecol Prog Ser 171:71-84

Submitted: September 17, 1998; Accepted: December 23, 1998 Proofs received from author(s): May 25, 1999 